\title{
As CONTRIBUIÇões dos BIODESAFIOS E BIOSIMULAdO NA FORMAÇÃo INICIAL DE PROFESSORES
}

\author{
The CONTRIBUtions of THE BioChallenge AND BioSimulated IN THE INITIAL \\ FORMATION OF TEACHERS
}

LAS CONTRIBUCIONES DE LOS BIODESAFIOS Y BIOSIMULADO EN LA FORMACIÓN INICIAL DE LOS MAESTROS

\author{
Fabiano Avelino Gonçalves \\ (iD) 9 \\ Doutorado em Biotecnologia \\ (UFRN) \\ Professor no Instituto Federal de \\ Mato Grosso (IFMT) \\ fabiano_avelinogoncalves@yahoo. \\ $\underline{\text { com.br }}$
}

\section{George Laylson da Silva \\ Oliveira \\ (iD) 9}

Doutorado em Biotecnologia

(UFPI)

Professor no Instituto Federal de

Mato Grosso (IFMT)

george.oliveira@gta.ifmt.edu.br

\section{Jepherson Correia Sales

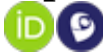

Mestrado em Geografia (UFMT)

Professor no Instituto Federal de

Mato Grosso (IFMT)

jepherson.sales@gta.ifmt.edu.br

\section{Rosangela Maria Pinheiro dos Santos Fernandes \\ iD 9}

Especialização em Mídias na

Educação (UFMT)

Técnica em Assuntos Educacionais no Instituto Federal de Mato

Grosso (IFMT)

rosangela.fernandes@gta.ifmt.edu. br

\begin{abstract}
Resumo
A população mundial encontra-se devastada pela pandemia viral provocada pelo novo coronavírus (COVID-19). Dentre as inúmeras atividades antrópicas afetadas, destaca-se a área educacional. Neste sentido, este projeto de ensino visou contribuir didático-pedagógico-científica na formação inicial de professores e familiarizá-los as avaliações externas a partir das aplicações dos BioDesafios, baseados em Questões Sociocientíficas (QSCs) e BioSimulado por meio das Tecnologias da Informação e Comunicação (TICs). Dessa forma, usando AVA Google sala de aula os BioDesafios (em grupo) foram aplicados semanalmente aos estudantes e o BioSimulado (individual) executado no final do projeto de ensino. Assim, as equipes estudantis constituídas para realizarem os BioDesafios semanais foram à ipê-amarelo (Tabebuia alba); onça-pintada (Panthera onca); árvore Guarantã (Esenbeckia leiocarpa) e arara-azul (Anodorhynchus hyacinthinus). Os BioDesafios apresentaram participação significativa das equipes, além da ação coletiva na elaboração do design expressos nas camisetas e adesivos das equipes. Ademais, os estudantes obtiveram rendimentos entre $42-88 \%$ no BioSimulado. Portanto, este projeto cooperou na formação dos estudantes, além de fortalecer o preparo estudantil para realização das avaliações externas, tais como, Enade, e também para o comportamento sanitário profilático apropriado durante a pandemia viral.

Palavras-chave: Projeto de ensino. Formação docente. Tecnologias da Informação e Comunicação (TICs). Questões sociocientíficas (QSCs). COVID-19.
\end{abstract}

Recebido em: 8 de janeiro de 2021.

Aprovado em: 5 de julho de 2021.

Como citar esse artigo (ABNT):

GONÇALVES, Fabiano Avelino et al. As contribuições dos BioDesafios e BioSimulado na formação inicial de professores.

Revista Prática Docente, v. 6, n. 2, e048, 2021.

http://doi.org/10.23926/RPD.2021.v6.n2.e048.id961 


\begin{abstract}
The world population is devastated by the viral pandemic caused by the new coronavirus (COVID-19). Among the countless anthropic activities affected, the educational area stands out. In this sense, this teaching project aimed to contribute didactic-pedagogical-scientific in the initial training of teachers and familiarize them to external evaluations, based on applications of BioChallenges (socio-scientific issues, in groups) and BioSimulated (individual) through Information and Communication Technologies (ICTs). In this way, using AVA Google classroom, BioDesafios (in groups) were applied weekly to students and BioSimulado (individual) was executed at the end of the teaching project. Thus, the student teams formed to conduct the weekly BioChallenges were the yellow ipe (Tabebuia alba); jaguar (Panthera onca); Guarantã tree (Esenbeckia leiocarpa) and macaw (Anodorhynchus hyacinthinus). The BioChallenges showed significant participation of the teams, in addition to collective action in the elaboration of the design expressed in the teams' t-shirts and stickers. Besides that, students achieved between $42-88 \%$ in the BioSimulated. Therefore, this project contributed to the training of students, in addition to strengthening student preparation for the performance of external evaluations, such as Enade, and also for appropriate prophylactic health behaviour during the viral pandemic.

Keywords: Teaching Project. Teacher training. Information and Communication Technologies (ICTs). Socio-scientific issues (SSIs). COVID-19.
\end{abstract}

\section{Resumen}

La población mundial está devastada por la pandemia viral provocada por el nuevo coronavirus (COVID-19). Entre las innumerables actividades antrópicas afectadas, destaca el área educativa. En este sentido, este proyecto docente tuvo como objetivo aportar didácticopedagógico-científico en la formación inicial del professorado y familiarícelos con las evaluaciones externas, basado en aplicaciones de BioDesafíos (cuestiones socio-científicas, en grupos) y Biosimulado (individual) a través de las Tecnologías de la Información y la Comunicación (TIC). Así, utilizando AVA Google en el aula, se aplicaron semanalmente BioDesafios (en grupos) a los alumnos y se ejecutó BioSimulado (individual) al finalizar el proyecto docente. De esa forma, los equipos de estudiantes formados para realizar los BioDesafíos semanales fueron el ipe amarillo (Tabebuia alba); jaguar (Panthera onca); árbol Guarantã (Esenbeckia leiocarpa) y guacamayo (Anodorhynchus hyacinthinus). Los BioDesafíos mostraron una participación significativa de los equipos, además de la acción colectiva en la elaboración del diseño expresado en las camisetas y pegatinas de los equipos. Además de eso, los estudiantes lograron entre $42-88 \%$ en Biosimulado. Por tanto, este proyecto contribuyó a la formación de los estudiantes, además de fortalecer la preparación de los estudiantes para la realización de evaluaciones externas, como Enade, y también para una adecuada conducta de salud profiláctica durante la pandemia viral. Palabras clave: Proyecto docente. Formación docente. Tecnologías de la información y la comunicación (TIC). Cuestiones sociocientíficas (SSI). COVID-19. 


\section{INTRODUÇÃO}

Entre as inúmeras ferramentas para fortalecer a qualidade da educação brasileira, destacam-se as Tecnologias da Informação e Comunicação (TICs), ferramenta basilar neste projeto de ensino, permitindo, em especial, aumentar o tempo da dedicação estudantil no processo de ensino e aprendizagem. Além disso, as TICs, permitem ainda, elevar a disponibilidade de acesso aos materiais didáticos e paradidáticos, motivar o ambiente escolar, a partir do uso das práticas inovadoras de ensino, além de apresentar atividades interdisciplinares e integradoras, e possibilitar a comunicação virtual (reuniões e fóruns a distância entre estudantes-estudantes, estudantes-professores e professores-professores). Dessa forma, permitindo o acolhimento, a competição educacional, realização de evento virtual e acompanhamento estudantil. Portanto, as TICs tornarão o processo de ensino e aprendizagem acessível, ágil, aprazível, atrativo e dinâmico (OLIVEIRA; MOITA, 2016).

As TICs, no âmbito educacional, segundo a Organização das Nações Unidas para a Educação, a Ciência e Cultura (UNESCO) apresentam capacidade transformadora de recursos tecnológicos em prol do processo de ensino e aprendizagem, fortalecendo os sistemas de educação, a disseminação do conhecimento e acesso à informação (UNESCO, 2016). Neste sentido, o processo de ensino e aprendizagem deve buscar recursos e instrumentos tecnológicos de modo a implantar diferentes metodologias de ensino (ALVES et al., 2015), e as atividades possibilitadora de ação e reflexão pelo estudante tornam-se preponderantes no processo de ensino e aprendizagem, como exemplo, Quizzes (desafios, testes, simulados e jogos), realizados individualmente ou em equipes contribuem de forma eficaz e lúdica no processo de construção do conhecimento e na avaliação estudantil (ARAÚJO et al., 2011).

Ademais, o emprego de questões (BioDesafios e BioSimulado) por meio das TICs, como metodologia de ensino poderá complementar a formação didático-pedagógico-científica dos estudantes e ainda, prepará-los para as avaliações externas, por exemplo, o Exame Nacional de Desempenho dos Estudantes (Enade). Essa avaliação mensura o rendimento dos estudantes concluintes dos cursos de graduação, em relação aos conteúdos programáticos, habilidades e competências adquiridas em sua trajetória formativa. $\mathrm{O}$ exame é obrigatório e a situação de regularidade do estudante deve constar em seu histórico escolar. A primeira aplicação do Enade ocorreu em 2004 e a periodicidade máxima da avaliação é trienal para cada área do conhecimento. A prova é constituída de duas partes: Formação Geral, composta por 10 (dez); Componentes Específicos, constituída de 30 (trinta) questões.

O exame contempla a particularidade de cada área e de suas eventuais modalidades, tanto no domínio dos conhecimentos, como nas habilidades esperadas para o perfil profissional 
(INEP, 2020). Nesta perspectiva, a edição 2020 do Enade foi regulamentada pela Portaria $\mathrm{n}^{\circ}$ 14/2020 e no art. $1^{\circ}$ da edição deste ano será aplicado aos estudantes dos cursos vinculados ao Ano II do Ciclo Avaliativo. Assim, abrange os estudantes do curso de licenciatura em Ciências da Natureza com Habilitação em Biologia do Instituto Federal de Educação, Ciência e Tecnologia de Mato Grosso (IFMT), Campus Avançado Guarantã do Norte, os quais estarão realizando essa avaliação externa. As provas estavam agendadas para o dia 22 de novembro de 2020, contudo, motivado pela pandemia viral, o exame foi adiado para 2021 (BRASIL, 2020).

Diante da necessidade de ampliar a assimilação de conteúdo pelos estudantes durante a sua formação inicial, assim, também contribuir na compreensão da importância e formato das avaliações externas, em especial, no que tange às questões de formação geral e dos componentes específicos contidas no Enade. Neste sentido, esse projeto de ensino visa complementar a formação inicial dos estudantes e familiarizá-los as avaliações externas a partir das elaborações e aplicações de BioDesafios didáticos-pedagógicos-científicos semanais, executados em grupos estudantis, baseados em Questões Sociocientíficas (QSCs) e de BioSimulado individual, com auxílio das TICs. Esses momentos suplementares para a prática do processo de ensino e aprendizagem são eminentes para diagnosticar os níveis de conhecimento e a assimilação de conhecimento apresentados pelos estudantes, além de se basear no feedback proferido pelos professores e técnicos educacionais, indicando assim, os aproveitamentos estudantis obtidos durante o projeto; a análise da eficiência dessa ação educacional nas atividades de estudos dos futuros professores; incentivar a regularidade de estudos; fornecer um ambiente motivador, competidor e investigador de aprendizagem ao desafiar os limites de conhecimentos dos estudantes e a prática das TICs. Além da oportunidade de familiarizar os estudantes, professores e técnicos educacionais do curso de licenciatura aos procedimentos e formatos das avaliações externas, como o Enade.

\section{REFERENCIAL TEÓRICO}

Em busca de amenizar as possíveis dificuldades apresentadas no decorrer do processo de ensino e aprendizagem da formação inicial de professores, influenciada principalmente pela pandemia viral da COVID-19, em especial, da necessidade de priorizar o distanciamento ou/e isolamento social, torna-se assim, eminente uso de estratégias educacionais, com destaque, do emprego das TICs. Essa estratégia foi evidenciada por Freire (1995):

Acho que o uso de computadores no processo de ensino/aprendizagem, em lugar de reduzir, pode expandir a capacidade crítica e criativa de nossos meninos e meninas. Depende de quem o usa, a favor de quê e de quem, e para quê. Já colocamos o essencial nas escolas; agora podemos pensar em colocar computadores. (FREIRE, 1995, p. 98). 
Nesse sentido, surge a oportunidade de fortalecer a trajetória formativa docente com uso das TICs, tanto individualmente, quanto em grupo. Segundo Venturini et al. (2019), o trabalho em grupo pode ser incentivado pela execução da forma colaborativa, proporcionando ambientes de aprendizagem. Assim, destaca-se como Ambiente Virtual de Aprendizagem (AVA), o Google sala de aula, AVA favorece o dinamismo no processo educacional, além das características colaborativa e comunicativa, tornando o processo de ensino e aprendizagem produtivo e significativo. De acordo com Da Silva, Figueira, Santos (2019), o AVA Google sala de aula consiste em uma concepção contemporânea para o processo de ensino e aprendizagem. Além disso, segundo Araújo (2016), o emprego das TICs potencializa o ensino transformador. No Quadro 1 são demonstradas algumas funcionalidades do AVA Google sala de aula.

\section{Quadro 1 - Algumas características do AVA Google sala de aula}

Quadro 1 - Algumas características do AVA Google sala de aula

\begin{tabular}{|c|c|}
\hline Benefício & Descrição \\
\hline $\begin{array}{c}\text { Fácil } \\
\text { configuração }\end{array}$ & $\begin{array}{l}\text { Os professores podem cadastrar e gerenciar a turma e ainda, convidar estudantes e professores } \\
\text { auxiliares. O mural da turma permite compartilhamento de informações, como: avisos, tarefas e } \\
\text { dúvidas/perguntas. }\end{array}$ \\
\hline $\begin{array}{l}\text { Poupa tempo e } \\
\text { papel }\end{array}$ & $\begin{array}{l}\text { Os professores podem distribuir atividades e atribuir notas sem usar papel, além de comunicar e manter } \\
\text { organizado em apenas um local. }\end{array}$ \\
\hline Organização & $\begin{array}{l}\text { Os estudantes podem ver as atividades na página denominada "Pendentes", no mural ou na agenda da } \\
\text { turma. Os materiais didáticos e paradidáticos são automaticamente inseridos em pastas do Google } \\
\text { Drive. Além disso, permite ao professor o preparo das atividades e programar o momento de } \\
\text { disponibilizá-las aos estudantes. Possibilita ainda, limitar a data de entrega das atividades e caso o } \\
\text { professor permita a entrega das atividades em atrasos, as mesmas apresentarão essa informação } \\
\text { registrada. }\end{array}$ \\
\hline $\begin{array}{l}\text { Comunicação e } \\
\text { feedback } \\
\text { aprimorados }\end{array}$ & $\begin{array}{l}\text { Os professores podem criar tarefas, enviar avisos e iniciar instantaneamente debates com a turma. Os } \\
\text { estudantes podem compartilhar recursos entre eles e interagir no mural da turma ou por correio } \\
\text { eletrônico. Os professores também podem ver rapidamente quem concluiu ou não a atividade enviada, } \\
\text { dar feedback direto, em tempo real e atribuir notas. }\end{array}$ \\
\hline $\begin{array}{l}\text { Sincroniza aos } \\
\text { aplicativos }\end{array}$ & $\begin{array}{l}\text { O AVA Google sala de aula funciona com os seguintes recursos: Docs Google, Google Agenda, } \\
\text { Gmail, Google Drive, Formulários Google, entre outros. }\end{array}$ \\
\hline $\begin{array}{l}\text { Acessível e } \\
\text { seguro }\end{array}$ & $\begin{array}{l}\text { O AVA Google sala de aula é gratuito, não exibe anúncios e veda o repasse de conteúdo do professor } \\
\text { ou dados dos estudantes para fins publicitários e verifica a originalidade das respostas contidas nas } \\
\text { atividades estudantis. Permite adicionar e/ou remover professores e estudantes da turma. Exigência dos } \\
\text { professores e estudantes conterem correio eletrônico da Google. }\end{array}$ \\
\hline
\end{tabular}

Fonte: Modificado de Silva (2018) e Google (2020).

O emprego do AVA Google sala de aula no processo de ensino e aprendizagem estudantil - formação inicial de professores - aliada à metodologia de ensino participativa, abrangendo as Questões Sociocientíficas (QSCs) aplicadas no formato de BioDesafios semanais (executado em equipe estudantil), associados ao BioSimulado (praticado individualmente) consistem em ferramentas didático-pedagógicas essenciais para o êxito na 
formação docente, além de possibilitar o fortalecimento do conhecimento estudantil diante também das avaliações externas, como exemplo, o Enade. Para Mercado (2017), torna-se eminente a aplicação das metodologias de ensino focadas nos estudantes, tornando-os protagonistas do processo de ensino e aprendizagem, a partir das descobertas, da motivação e do desenvolvimento de suas competências e habilidades. Segundo Silva (2018), na era da conectividade social, a escolha por opção de metodologia de ensino passiva transformará a aprendizagem estudantil insignificante. Ademais, Ribeiro (2020), categoriza as metodologias participativas (MPs) na qualidade de metodologias de ensino e aprendizagem participativas, problematizadoras e colaborativas.

Ainda, Ribeiro (2020), salienta o uso das QSCs de maneira proveitosa e significativa no processo de ensino e aprendizagem, além das QSCs propiciarem protagonismo estudantil nesse processo. Essa informação corrobora com as afirmações descritas a seguir por Conrado (2017):

\begin{abstract}
As QSCs são importantes situações ou problemas complexos ou pouco definidos, que envolvem conteúdos inter ou multidisciplinares, sendo que os conhecimentos científicos são fundamentais para a compreensão e a busca de soluções para estes problemas. Abordar temas relacionados diretamente com o contexto dos estudantes facilita seu envolvimento e aumenta a possibilidade de discussão e percepção sobre diversos aspectos da situação, além de permitir participação real nos processos de tomada de decisão. O engajamento e a aproximação afetiva/emocional auxiliam na percepção de que o estudante é um responsável direto e, por isso, necessário para promover mudanças no sentido de resolver ou mitigar os problemas socioambientais atuais, sejam aqueles que o afetam diretamente ou indiretamente (CONRADO, 2017, p. 83).
\end{abstract}

Durante a formação inicial de professores surge a possibilidade e potencialidade de uso das QSCs. Segundo Ribeiro (2016, 2020), as QSCs apresentam empregabilidade nos níveis de ensino (educação básica e educação superior), abrangendo assim, a formação docente, além de oportunizar o uso das TICs. Nesse sentido, a legislação educacional brasileira, em especial, a Lei $n^{\circ}$ 9.394/1996 (BRASIL, 1996), determina alguns requisitos para a formação inicial de professores:

Art. 62. A formação de docentes para atuar na educação básica far-se-á em nível superior, em curso de licenciatura plena, admitida, como formação mínima para o exercício do magistério na educação infantil e nos cinco primeiros anos do ensino fundamental, a oferecida em nível médio, na modalidade normal. $\S 3^{\circ} \mathrm{A}$ formação inicial de profissionais de magistério dará preferência ao ensino presencial, subsidiariamente fazendo uso de recursos e tecnologias de educação a distância. (BRASIL, 2009).

Além disto, a Resolução CNE/MEC n 2/2019, apresenta as Diretrizes Curriculares Nacionais para a formação inicial de professores para lecionarem na educação básica e institui ainda, a Base Nacional Comum para a formação inicial de professores da educação básica (BNC-Formação) (BRASIL, 2019). Essas Diretrizes foram assentes nas determinações contidas 
na Base Nacional Comum Curricular, instituída pela Lei nº 13.415/2017 (BRASIL, 2017) e define:

Art. $2^{\circ}$ A formação docente pressupõe o desenvolvimento, pelo licenciando, das competências gerais previstas na BNCC-Educação Básica, bem como das aprendizagens essenciais a serem garantidas aos estudantes, quanto aos aspectos intelectual, físico, cultural, social e emocional de sua formação, tendo como perspectiva o desenvolvimento pleno das pessoas, visando à Educação Integral. (BRASIL, 2019).

Nas competências específicas:

Art. $4^{\circ}$ As competências específicas se referem a três dimensões fundamentais, as quais, de modo interdependente e sem hierarquia, se integram e se complementam na ação docente. São elas: I - conhecimento profissional; II - prática profissional; e III engajamento profissional (BRASIL, 2019).

As dimensões fundamentais: prática profissional (2.1 e 2.3); engajamento profissional (3.4) demandam competências específicas/habilidades, com inclusão das TICs durante a formação inicial de professores:

2.1 Planejar ações de ensino que resultem em efetivas aprendizagens: 2.1.5 Realizar a curadoria educacional, utilizar as tecnologias digitais, os conteúdos virtuais e outros recursos tecnológicos e incorporá-los à prática pedagógica, para potencializar e transformar as experiências de aprendizagem dos estudantes e estimular uma atitude investigativa. 2.3 Avaliar o desenvolvimento do educando, a aprendizagem e o ensino: 2.3.5 Fazer uso de sistemas de monitoramento, registro e acompanhamento das aprendizagens utilizando os recursos tecnológicos disponíveis. 3.4 engajar-se profissionalmente, com as famílias e com a comunidade: 3.4.3 Saber comunicar-se com todos os interlocutores: colegas, pais, famílias e comunidade, utilizando os diferentes recursos, inclusive as tecnologias da informação e comunicação. (BRASIL, 2019).

No decorrer da formação inicial de professores se pleiteia o conhecimento relacionado aos fundamentos científicos e sociais, nessa continuidade, as QSCs poderão contribuir para o fortalecimento desse fundamento. A seguir encontra-se o art. $5^{\circ}$ da legislação educacional:

Art. 5o A formação dos professores e demais profissionais da Educação, conforme a Lei de Diretrizes e Base da Educação Nacional (LDB), para atender às especificidades do exercício de suas atividades, bem como aos objetivos das diferentes etapas e modalidades da Educação Básica, tem como fundamentos: I - a sólida formação básica, com conhecimento dos fundamentos científicos e sociais de suas competências de trabalho; [...]. (BRASIL, 2019).

Os cursos destinados à formação inicial de professores demandam na organização curricular de alguns princípios norteadores e de fundamentos pedagógicos, como: direito a aprender; protagonismo; autonomia; metodologias inovadoras; projetos interdisciplinares e TICs. Conforme descritos nos fragmentos dos art. $7^{\circ}$ e $8^{\circ}$ da Resolução mencionada:

Art. $7^{\circ} \mathrm{A}$ organização curricular dos cursos destinados à Formação Inicial de Professores para a Educação Básica, em consonância com as aprendizagens prescritas na BNCC da Educação Básica, tem como princípios norteadores: [...] IV reconhecimento do direito de aprender dos ingressantes, ampliando as oportunidades de desenvolver conhecimentos, habilidades, valores e atitudes indispensáveis para o bom desempenho no curso e para o futuro exercício da docência; VI - fortalecimento 
da responsabilidade, do protagonismo e da autonomia dos licenciandos com o seu próprio desenvolvimento profissional; [...] XII - aproveitamento dos tempos e espaços da prática nas áreas do conhecimento, nos componentes ou nos campos de experiência, para efetivar o compromisso com as metodologias inovadoras e projetos interdisciplinares, flexibilização curricular, construção de itinerários formativos, projeto de vida dos estudantes, dentre outros; Art. $8^{\circ}$ Os cursos destinados à Formação Inicial de Professores para a Educação Básica devem ter como fundamentos pedagógicos: [...] II - o compromisso com as metodologias inovadoras e com outras dinâmicas formativas que propiciem ao futuro professor aprendizagens significativas e contextualizadas em uma abordagem didático-metodológica alinhada com a BNCC, visando ao desenvolvimento da autonomia, da capacidade de resolução de problemas, dos processos investigativos e criativos, do exercício do trabalho coletivo e interdisciplinar, da análise dos desafios da vida cotidiana e em sociedade e das possibilidades de suas soluções práticas; [...] IV - emprego pedagógico das inovações e linguagens digitais como recurso para o desenvolvimento, pelos professores em formação, de competências sintonizadas com as previstas na BNCC e com o mundo contemporâneo; [...]. (BRASIL, 2019).

Nesse sentido, o uso de BioDesafios baseadas em QSCs e o BioSimulado por meio das TICs, além de complementar a formação didático-pedagógico-científica dos estudantes, poderá prepará-los para as avaliações externas, por exemplo, o Exame Nacional de Desempenho dos Estudantes (Enade). Este possui o intuito de avaliar os estudantes concluintes dos cursos superiores brasileiros, foi criado e aplicado, em 2004. A primeira avaliação estudantil de caráter nacional e obrigatório:

O Exame Nacional de Desempenho dos Estudantes (Enade) avalia o rendimento dos concluintes dos cursos de graduação em relação aos conteúdos programáticos previstos nas diretrizes curriculares dos cursos, o desenvolvimento de competências e habilidades necessárias ao aprofundamento da formação geral e profissional, e o nível de atualização dos estudantes com relação à realidade brasileira e mundial. (INEP, 2020).

\section{Metodologia}

Com intuito de aproveitar esse momento de distanciamento e/ou isolamento social promovido pela pandemia viral, este projeto de ensino oportunizou aos estudantes do curso de licenciatura em Ciências da Natureza com Habilitação em Biologia do Campus Avançado Guarantã do Norte, pertencente ao IFMT à oferta por meio do AVA Google sala de aula e demais ferramentas digitais, tais como, Formulários Google e Google Meet às aplicações dos BioDesafios (realizados em grupo estudantil, baseados na QSCs) e BioSimulado (executado individualmente), em busca de proporcionar o fortalecimento do processo de ensino e aprendizagem, e emprego das TICs durante a formação inicial de professores, além de familiarizar os estudantes às avaliações externas, em especial, do Enade. Essas ferramentas tecnológicas aplicadas na educação também possibilitam a comunicação e interação entre os estudantes-estudantes; estudantes-professores; e professores-professores (VENTURINI, 2019).

O projeto de ensino abrangeu as disciplinas contidas na matriz curricular do curso de licenciatura supracitado. Os BioDesafios foram direcionados à turma do $7^{\circ}$ semestre do curso 
de licenciatura em Ciências da Natureza com Habilitação em Biologia do Campus Avançado. A escolha por essa turma foi motivada pelas iminências da conclusão do curso pelos estudantes e a realização da avaliação externa - Enade -. Além disso, foram realizadas reuniões on-line pelo Google Meet para a distribuição de tarefas entre os integrantes, com proeminência, no acompanhamento, alinhamento e avaliação dos procedimentos educacionais contidos no projeto.

Os BioDesafios semanais foram realizados em grupos estudantis e baseados na metodologia participativa destacada por Ribeiro (2020), baseadas em QSCs e postados semanalmente no AVA Google sala de aula da turma do $7^{\circ}$ semestre do curso de licenciatura. No mural do AVA Google sala de aula foram adicionados os documentos e informações sobre o projeto de ensino, além da escolha do nome da turma e slogan. Esses BioDesafios continham enunciados, vídeos, reportagens e artigos científicos, e foram respondidos por meio do Formulários Google, no formato de questão objetiva (escolha de opção) e justificar a sua resposta ou, no formato de questão discursiva. Alguns desses BioDesafios estavam voltados à educação sanitária motivada pela pandemia viral (COVID-19). Portanto, como os BioDesafios possuem característica coletiva, o BioDesafios 01 foi relativo à formação de 4 grupos estudantis, além das escolhas das mascotes e as cores de identificação das equipes. Essas informações, a partir de fomento recebido do IFMT, foram expressas em camiseta e adesivos, distribuídas aos integrantes. Dessa forma, fomentar a interação entre os participantes (VENTURINI, 2019); incentivar o protagonismo estudantil (RIBEIRO, 2020); construir conhecimento colaborativo e a avaliação estudantil (ARAÚJO et al., 2011).

Ainda, os estudantes realizaram o BioSimulado de forma individualizado, composto por 40 questões (10 questões de Formação Geral: 2 discursivas e 8 de múltipla escolha; 30 questões dos Componentes Específicos: 3 discursivas e 27 de múltipla escolha) e duração de 4 horas. Esses procedimentos utilizados foram similares as normas contidas no edital da edição Enade 2020. O BioSimulado foi postado no AVA Google sala de aula usando Formulários Google e contendo questões oriundas do banco de questões. Este banco foi composto por questões aplicadas em anos anteriores do Enade (http://portal.inep.gov.br/web/guest/educacaosuperior/enade/provas-e-gabaritos) e de questões similares ao Enade, além das questões de atualidades, interpretações de textos, tabelas e gráficos. Desse modo, os professores e técnicos educacionais foram responsáveis pela triagem, seleção e/ou elaboração dessas questões.

As questões utilizadas nos BioDesafios e BioSimulado continham gabaritos no formato digital comentados pelos professores e técnicos educacionais, permitindo assim, feedback ao estudante, do mesmo modo, aos demais professores e técnicos educacionais sobre o 
aproveitamento e progresso estudantil, a partir das análises quantitativa e qualitativa dos resultados obtidos. E também da possibilidade de verificar as possíveis lacunas e fragilidades no conhecimento estudantil.

\section{Resultados E Discussão}

\subsection{EQUIPES, ESCOLHAS DE MASCOTE, DA COR, DO DESIGN DAS CAMISETAS E ADESIVOS}

Primeiramente, foi criada a turma do "Projeto de Ensino - BioDesafios", com o slogan "Cada estudante possui o seu brilho e unidos formaremos uma constelação" no AVA Google sala de aula, os documentos e informações sobre o projeto foram inseridos no mural. Nesse sentido, no AVA Google sala de aula/Formulários Google, o BioDesafios 01 resultou na composição de quatro equipes, abrangendo os estudantes do $7^{\circ}$ semestre do curso de licenciatura em Ciências da Natureza com Habilitação em Biologia para as realizações dos demais BioDesafios, cada uma, contendo o líder da equipe, a indicação da mascote (um ser vivo da região alusivo em um dos cinco reinos) e uma cor.

Assim, o BioDesafios 01, obteve as seguintes equipes para realizarem os BioDesafios: ipê-amarelo (Tabebuia alba) e cor amarela; onça-pintada (Panthera onca) e cor verde; árvore Guarantã (Esenbeckia leiocarpa) e cor vermelha e arara-azul (Anodorhynchus hyacinthinus) e cor azul (Quadro 2). E também a ação coletiva na elaboração do design expressado nas camisetas (Figura 1) e nos adesivos (Figuras 2 A e B) das equipes estudantis. Ademais, durante a execução do BioDesafios 01, os estudantes apresentaram interesse nas TICs manuseadas no projeto de ensino e também pela possibilidade de interação e discussão coletiva por meios tecnológicos. Segundo Araújo (2016), na educação, o uso de recursos tecnológicos possibilita fomentar o ambiente ativo para o processo de aprendizagem. 
Quadro 2 - Escolha e significado da seleção de mascote concernente em um dos 5 reinos (Reino Monera, Protista, Fungi, Plantas e Animais) pertencente a região norte de Mato Grosso e a cor de identificação da equipe

\begin{tabular}{|c|c|c|c|c|}
\hline BioDesafios & $\begin{array}{c}\text { Escolha de mascote (nome } \\
\text { popular e científico) }\end{array}$ & Justificativa da escolha da mascote & Escolha da cor \\
\hline Equipe 1 & $\begin{array}{c}\text { Ipê-amarelo } \\
\text { (Tabebuia alba) }\end{array}$ & $\begin{array}{c}\text { É uma espécie presente na região, que embeleza } \\
\text { Guarantã do Norte-MT no período de floração. }\end{array}$ & Amarela \\
\hline Equipe 2 & $\begin{array}{c}\text { Onça-pintada } \\
\text { (Panthera onca) }\end{array}$ & $\begin{array}{c}\text { Espécie comumente encontrada em todo estado } \\
\text { do Mato Grosso, na região de Guarantã do } \\
\text { Norte-MT e Novo Mundo-MT são facilmente } \\
\text { encontradas nas matas da região rural. }\end{array}$ & Verde \\
\hline Equipe 4 & $\begin{array}{c}\text { Árvore Guarantã } \\
\text { (Esenbeckia leiocarpa) }\end{array}$ & $\begin{array}{c}\text { Árvore Guarantã devido ser uma árvore típica } \\
\text { da nossa região e consiste em uma madeira } \\
\text { conhecida por sua resistência. }\end{array}$ & Vermelha \\
\hline (Anodorhynchus hyacinthinus) & $\begin{array}{c}\text { Aue vive nos biomas da Floresta Amazônica e } \\
\text { principalmente no Cerrado e Pantanal. }\end{array}$ & Azul \\
\hline
\end{tabular}

Fonte: Dados da atividade realizada.

O projeto de ensino obteve fomento do IFMT e esse recurso financeiro oportunizaram as aquisições de camisetas (Figura 1) e itens de publicidade, como adesivos (Figuras 2 A e B), distribuídos aos integrantes, com a finalidade de fortalecer a participação, interação, competitividade e sentimento de pertencimento dos envolvidos no projeto de ensino, proporcionando êxito no BioDesafios 01, apesar do projeto ocorrer no formato digital, mantido o distanciamento e/ou isolamento social dos participantes, conforme as orientações da Anvisa (2020).

Figura 1 - Camiseta do Projeto Ensino - BioDesafios contendo as mascotes e as cores das equipes estudantis

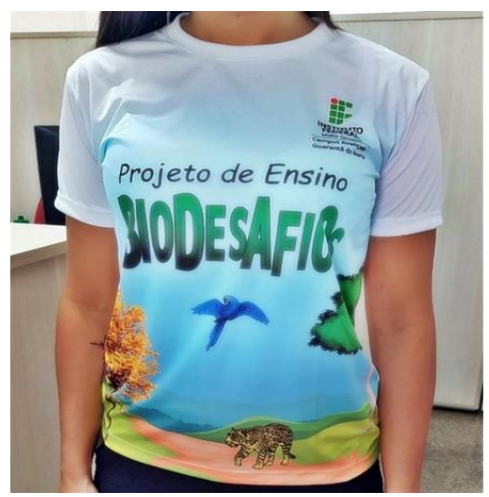

Fonte: Dados da atividade realizada 
Figura 2 - A) Adesivos do Projeto Ensino - BioDesafios contendo as mascotes e cores das equipes estudantis. B) Adesivo do Projeto Ensino - BioDesafios colado no notebook e presença de umas das mascotes, a árvore Guarantã

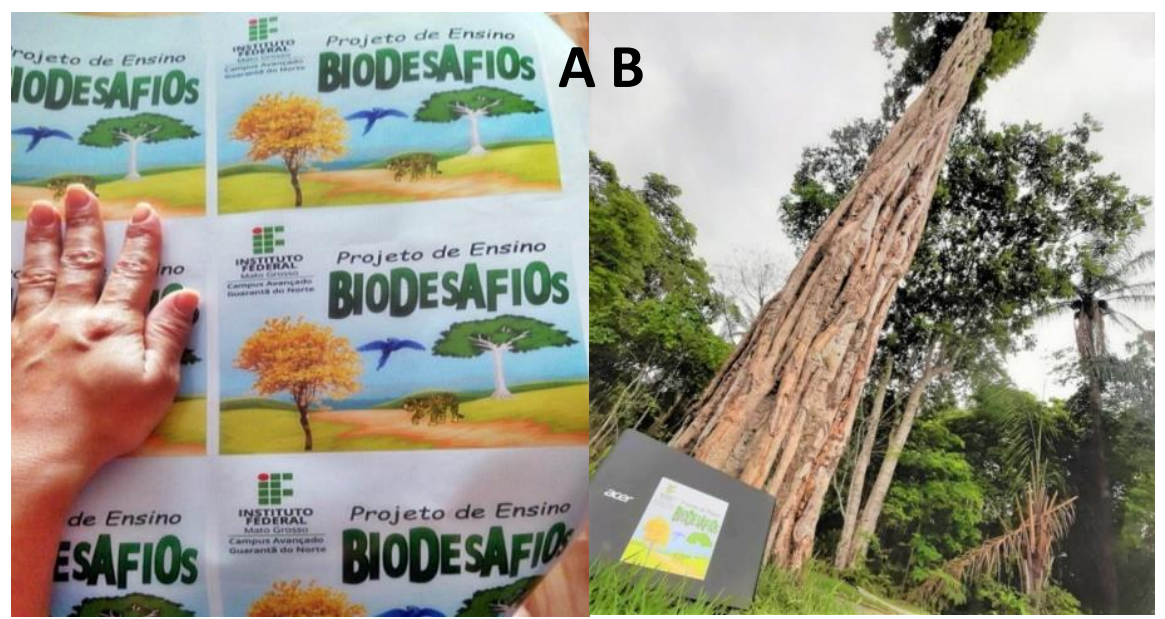

Fonte: Dados da atividade realizada.

Baseado no momento contemporâneo de saúde mundial motivado pela pandemia viral (COVID-19), a Organização Mundial de Saúde (OMS) pertencente à Organização das Nações Unidas (ONU) e adotadas por inúmeros países, estados (províncias) e municípios têm recomendado inúmeras práticas sanitárias, dentre elas, as orientações de distanciamento e/ou isolamento social (ANVISA, 2020). Neste sentido, durante esse período, a internet consiste numa das ferramentas fundamentais para a sociedade, porque, além de ser uma ferramenta de interação social, pesquisa e estudo, possibilita ainda, a comunicação à distância entre as pessoas. Assim, essa ferramenta auxiliou na educação formal, em prol do processo de ensino e aprendizagem estudantil significativo.

\subsection{BIODESAFIOS SEMANAIS}

A etapa de BioDesafios obteve participação significativa e exitosa das 4 equipes estudantis do projeto de ensino, como demonstrado no Quadro 3. Esses resultados são corroborados com as informações descritas por Conrado (2017), o emprego das QSCs abrangendo temáticas contextualizadas à realidade estudantil oportuniza a adesão e incentiva a discussão em grupo sobre o assunto. Para Ribeiro (2020), as QSCs são capazes de discutir temáticas de amplitude local, regional, nacional ou mundial. Além disso, o uso das QSCs contribui na assimilação dos conteúdos científicos (REIS, 2013). 
Quadro 3 - BioDesafios semanais

\begin{tabular}{|c|c|c|c|c|c|}
\hline Questão & $\begin{array}{c}\text { Nível de } \\
\text { dificuldade }\end{array}$ & Temática & Formato & $\begin{array}{c}\text { Porcentagem } \\
\text { de acerto da } \\
\text { equipe }(\%) \\
\end{array}$ & Fonte \\
\hline BioDesafios - 01 & Fácil & $\begin{array}{c}\text { Formação das } \\
\text { equipes, escolhas } \\
\text { das mascotes e } \\
\text { cores }\end{array}$ & Não se aplica & Não se aplica & Autoria própria \\
\hline BioDesafios - 02 & Moderada & $\begin{array}{l}\text { Objetivos de } \\
\text { Desenvolvimento } \\
\text { Sustentável da } \\
\text { ONU } \\
\end{array}$ & $\begin{array}{l}\text { Questão objetiva } \\
\text { (escolha de opção) e } \\
\text { justificar a resposta. }\end{array}$ & 100 & $\begin{array}{l}\text { Questão n. } \\
\text { 8/Enade } 2017 \\
\text { (INEP, 2017) }\end{array}$ \\
\hline BioDesafios - 03 & Difícil & BNCC & Questão discursiva. & 100 & Autoria própria \\
\hline BioDesafios - 04 & Moderada & $\begin{array}{l}\text { Queimadas legais e } \\
\text { ilegais no Pantanal }\end{array}$ & $\begin{array}{c}\text { Questão objetiva } \\
\text { (escolha de opção) e } \\
\text { justificar a resposta. }\end{array}$ & 100 & Autoria própria \\
\hline BioDesafios - 05 & Moderada & $\begin{array}{l}\text { Nova classificação } \\
\text { de seres vivos }\end{array}$ & $\begin{array}{l}\text { Questão objetiva } \\
\text { (escolha de opção) e } \\
\text { justificar a resposta. }\end{array}$ & 100 & Autoria própria \\
\hline BioDesafios - 06 & Fácil & $\begin{array}{l}\text { Profissão de } \\
\text { Biólogo na } \\
\text { profilaxia da } \\
\text { COVID-19 }\end{array}$ & $\begin{array}{c}\text { Questão } \\
\text { somatória/exemplificar a } \\
\text { resposta. }\end{array}$ & 100 & Autoria própria \\
\hline BioDesafios - 07 & Difícil & $\begin{array}{c}\text { Gestão } \\
\text { democrática e } \\
\text { Projeto Político } \\
\text { Pedagógico }\end{array}$ & $\begin{array}{l}\text { Questão objetiva } \\
\text { (escolha de opção) e } \\
\text { justificar a resposta }\end{array}$ & 100 & Autoria própria \\
\hline BioDesafios - 08 & Difícil & $\begin{array}{l}\text { Competências dos } \\
\text { entes federados } \\
\text { para a oferta da } \\
\text { educação }\end{array}$ & $\begin{array}{l}\text { Questão objetiva } \\
\text { (escolha de opção) e } \\
\text { justificar a resposta }\end{array}$ & 100 & Autoria própria \\
\hline BioDesafios - 09 & Difícil & Evolução biológica & $\begin{array}{c}\text { Questão objetiva } \\
\text { (escolha de opção) e } \\
\text { justificar a resposta }\end{array}$ & 100 & Autoria própria \\
\hline
\end{tabular}

Fonte: Dados da atividade realizada.

Alguns desses BioDesafios, baseados em QSCs, incluíam informações norteadoras, suplementadas por conceitos, hipóteses e/ou opiniões expressadas de formas convergentes e/ou divergentes e/ou conspiratórias em relação à proposição principal, como exemplo, nas temáticas dos BioDesafios: Queimadas legais e ilegais no Pantanal; Profissão de Biólogo na profilaxia da COVID-19; Evolução biológica (Quadro 3). Em conformidade com Fullick e Ratcliffe (1996) e Conrado (2017), as QSCs possibilitam aos estudantes manterem o foco no problema e investigar as possíveis soluções, além de estimular as discussões das temáticas e as análises das possíveis explicações didático-científicas discordantes, trilhando determinados objetivos de aprendizagem. Segundo Sadler (2004) e Reis (2013), as QSCs contribuem no desenvolvimento cognitivo, social, político, moral e ético dos estudantes. A metodologia de ensino empregada nos BioDesafios foi baseada na metodologia participativa evidenciada por Ribeiro (2020). Contribuindo assim, na participação significativa dos estudantes e tornando-os protagonistas no processo de ensino e aprendizagem. Além disso, na etapa de formação inicial de professores, a 
prática de BioDesafios por meio da metodologia participativa oportuniza aos mesmos, vivenciar maior número de ferramentas pedagógicas durante a sua trajetória formativa. Essas ferramentas ainda favorecem e fortalecem o emprego das TICs na educação.

\subsection{BIOSIMULADO}

A etapa de BioSimulado - com 40 questões de múltipla escolha e discursiva relativas à formação geral e componentes específicos - aplicado aos estudantes, resultou em aproveitamentos estudantis entre 42 e $88 \%$, com média global de $71,65 \%$ de acertos nas questões (Figura 3). Segundo Barbosa e Martins (2000), a possibilidade de elevar a abrangência da avaliação e assim, aumentar a complexidade de conhecimento necessária para obter resultado satisfatório, oportunizará ao estudante à aprendizagem, a partir da mensura dos seus saberes e primordialidade em desenvolvê-los.

Figura 3 - Aproveitamento estudantil no BioSimulado

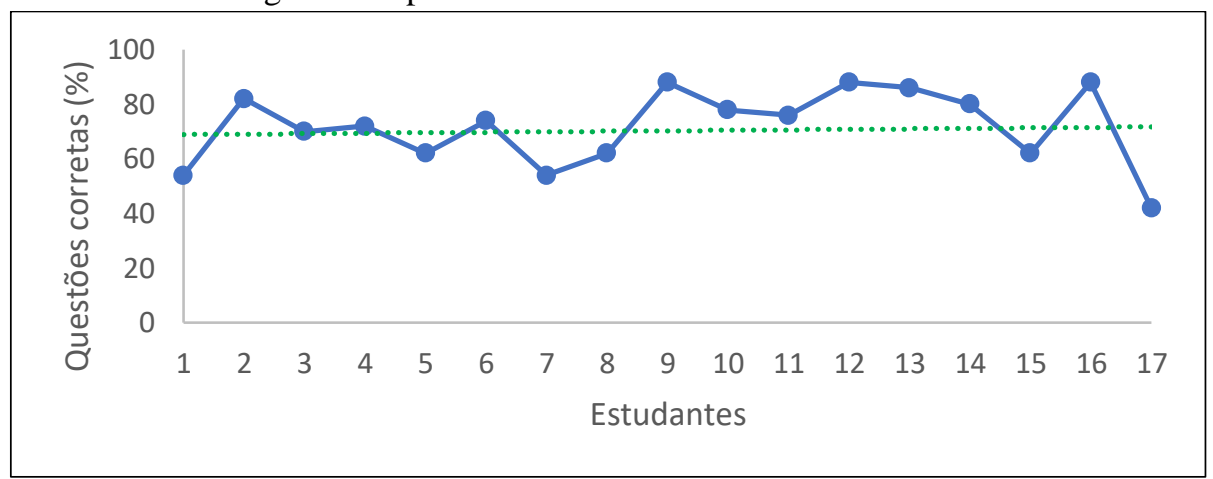

Fonte: Dados da atividade realizada.

Diante disso, espera-se o rendimento estudantil adequado diante das avaliações externas, como o Enade, e de comportamento sanitário apropriado durante a delonga da pandemia viral. Essas ações educacionais foram importantes para fortalecer a formação inicial de professores do curso de licenciatura em Ciências da Natureza com Habilitação em Biologia do Campus Avançado.

\subsection{Avaliação E autoavaliação estudantis relativos aOS BioDesafios E BIOSIMULAdo}

Baseado na metodologia de ensino participativa mencionada por Ribeiro (2020), a etapa de avaliar e autoavaliar o projeto de ensino, em especial, dos BioDesafios e BioSimulado tornam-se significativos para o processo de ensino e aprendizagem. Nesse sentido, são apresentadas nas Figuras 4-16 e nos Quadros 4 e 5 as informações avaliativas dos 17 estudantes participantes do projeto (17 respostas) sobre os BioDesafios e BioSimulado. Além disso, o 
emprego das TICs e da metodologia de ensino podem ter contribuído para a formação inicial de professores (Figura 13).

As Figuras 4 e 5 apresentam a avaliação dos BioDesafios pelos estudantes. Dessa maneira, os BioDesafios apresentaram graus de dificuldades medianos e não foram citados os graus de dificuldades "Muito fácil" e "Muito difícil" (Figura 4). Além disso, conforme os estudantes, os enunciados dos BioDesafios foram claros e objetivos (Figura 5). E as Figuras 610 evidenciam a avaliação estudantil sobre o BioSimulado. Assim, destacam os graus de dificuldades medianos nas partes de Componente Específico e Formação Geral (Figuras 6 e 7), além de apresentarem clareza e objetividade (Figuras 8 e 9). Em relação à extensão das questões contidas no BioSimulado relativo ao tempo total - 4 horas -, a maioria dos estudantes considerou a extensão das questões adequadas. Portanto, a avaliação pelos estudantes desse processo de ensino e aprendizagem torna-se eminente para o êxito da metodologia participativa.

Figura 4 - Avaliação dos BioDesafios

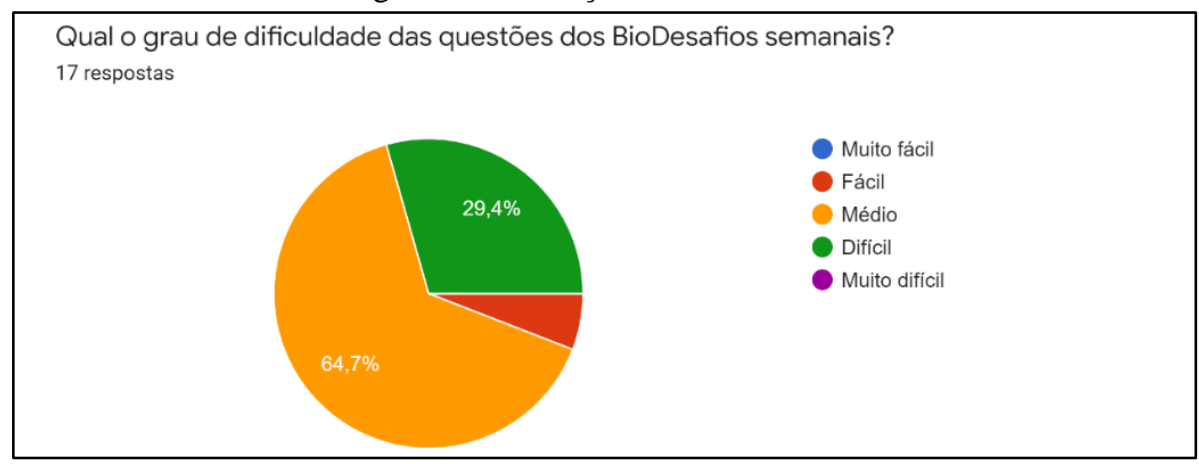

Fonte: Dados da atividade realizada.

Figura 5 - Avaliação dos BioDesafios

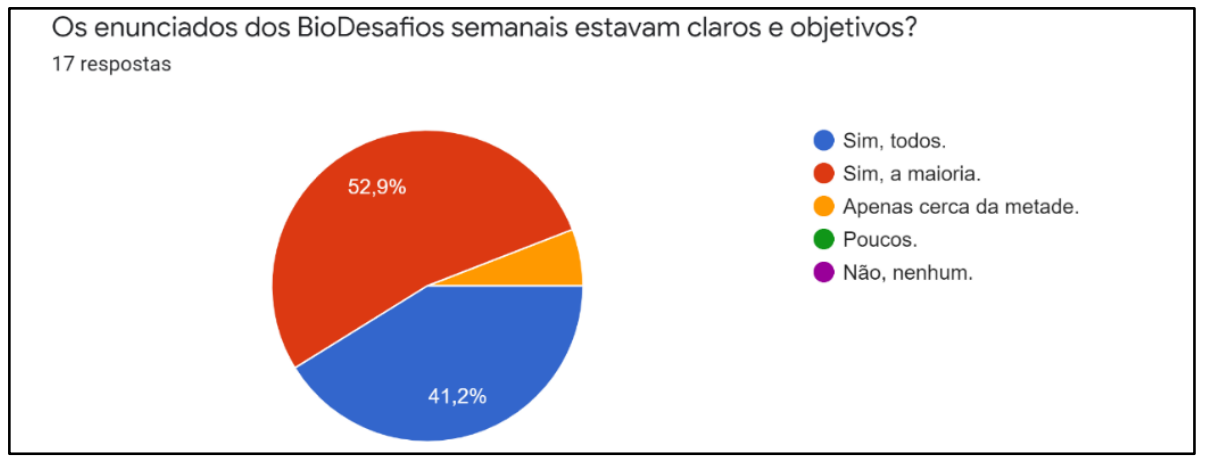

Fonte: Dados da atividade realizada. 
Figura 6 - Avaliação do BioSimulado

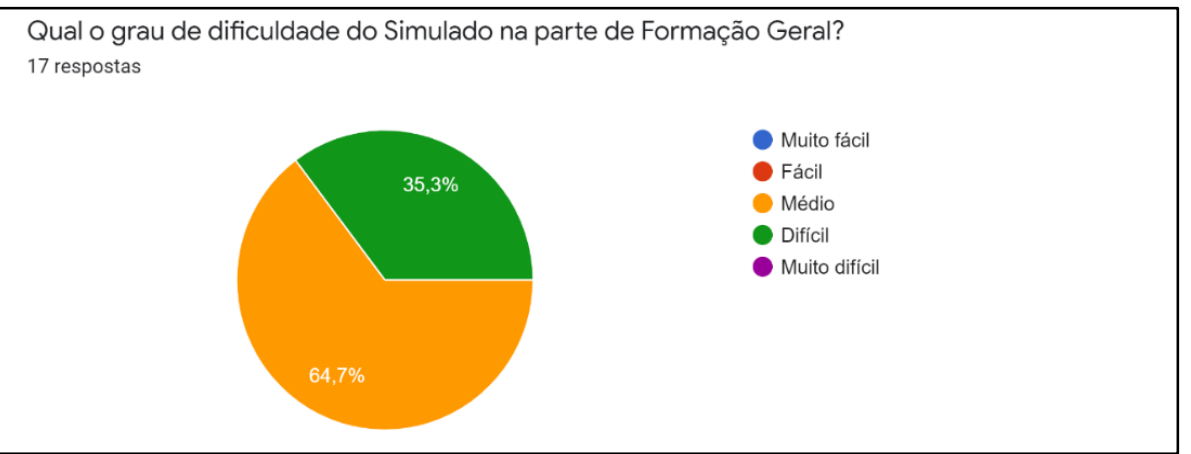

Fonte: Dados da atividade realizada.

Figura 7 - Avaliação do BioSimulado

$\begin{aligned} & \text { Os enunciados das questões do Simulado na parte de Formação Geral estavam claros e objetivos? } \\ & 17 \text { respostas }\end{aligned}$

Fonte: Dados da atividade realizada.

Figura 8 - Avaliação do BioSimulado

Qual o grau de dificuldade do Simulado na parte de Componente Especifico? 17 respostas

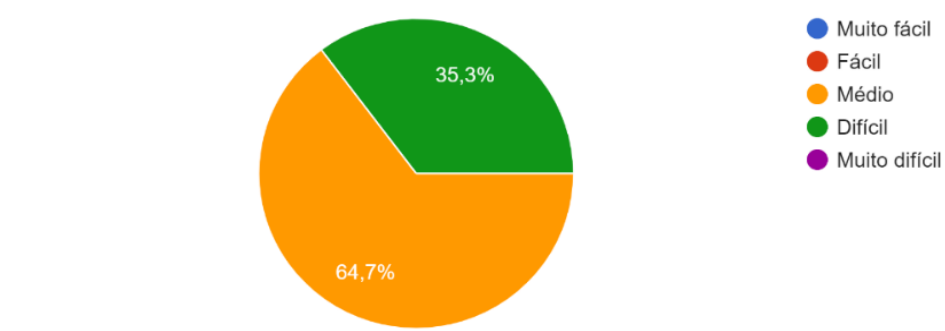

Fonte: Dados da atividade realizada.

Figura 9 - Avaliação do BioSimulado

$\begin{aligned} & \text { Os enunciados das questões do Simulado na parte de Componente Especifico estavam claros e } \\ & \text { objetivos? } \\ & 17 \text { respostas } \\ & \end{aligned}$

Fonte: Dados da atividade realizada. 
Figura 10 - Avaliação do BioSimulado

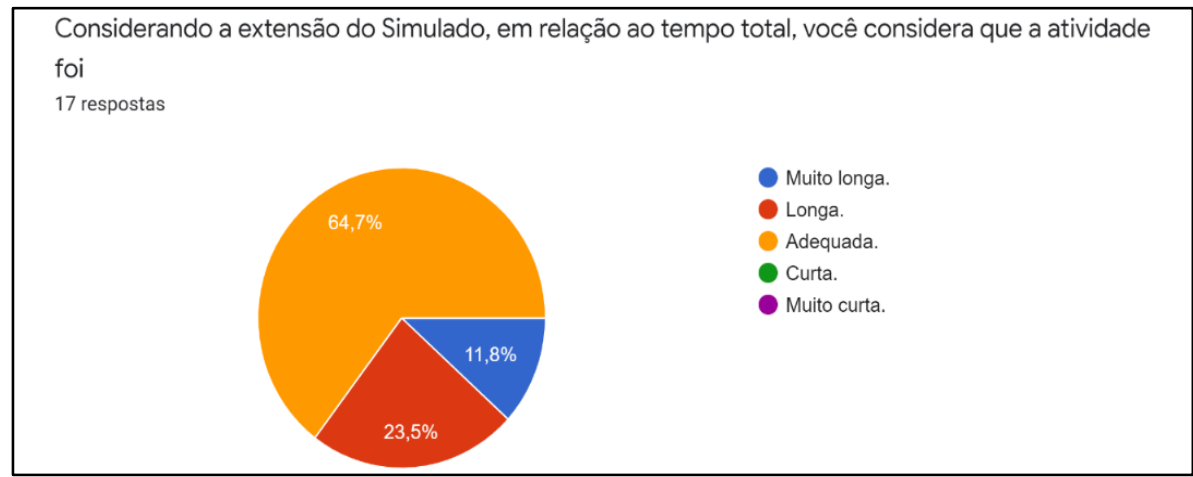

Fonte: Dados da atividade realizada.

As Figuras 11 e 12 demostram a adaptação estudantil à abordagem metodológica proposta pelo projeto de ensino. Esses realizaram as atividades no prazo preestabelecido, evidenciando assim, elevado interesse estudantil durante o projeto. Entretanto, cerca de $15 \%$ dos estudantes relataram desmotivação e outros $20 \%$, desconhecimento do conteúdo abordado em uma ou mais questões utilizadas no decorrer do projeto. Nesse cenário, uma das possíveis causas atribuídas consiste no procedimento de se adequar a vivência de estudos dos docentes e discentes no formato de ensino a distância, tornando-se necessário se adaptar e construir novos ritos e ritmos diferentes de estudo, quando comparado ao ensino presencial. Nesse caminho, alguns estudantes apresentaram dificuldade em adquirir a autonomia, parte essencial para o sucesso educacional (BAZHUNI et. al., 2020; CAFÉ et. al., 2020).

Figura 11 - Avaliação dos BioDesafios

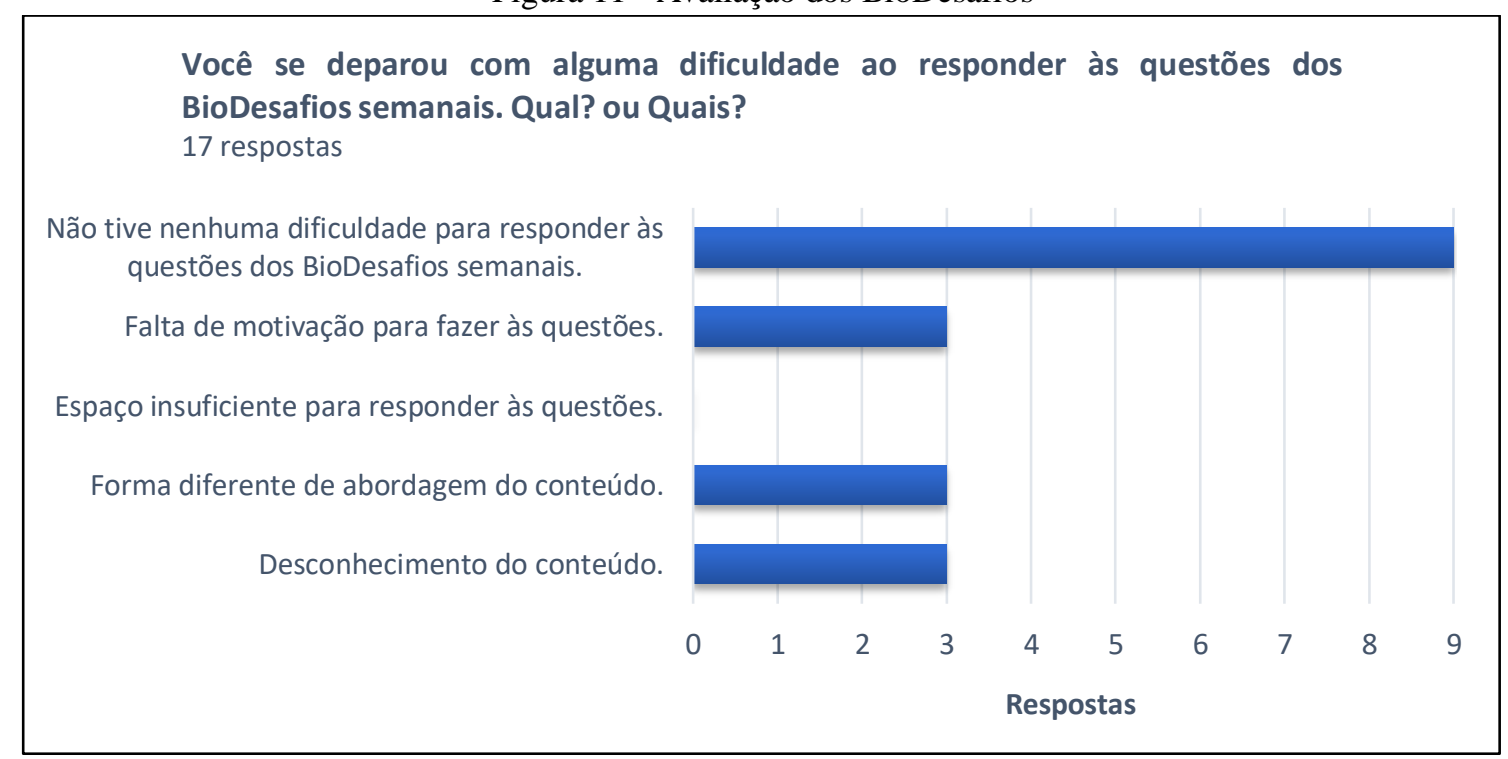

Fonte: Dados da atividade realizada. 
Figura 12 - Avaliação do BioSimulado

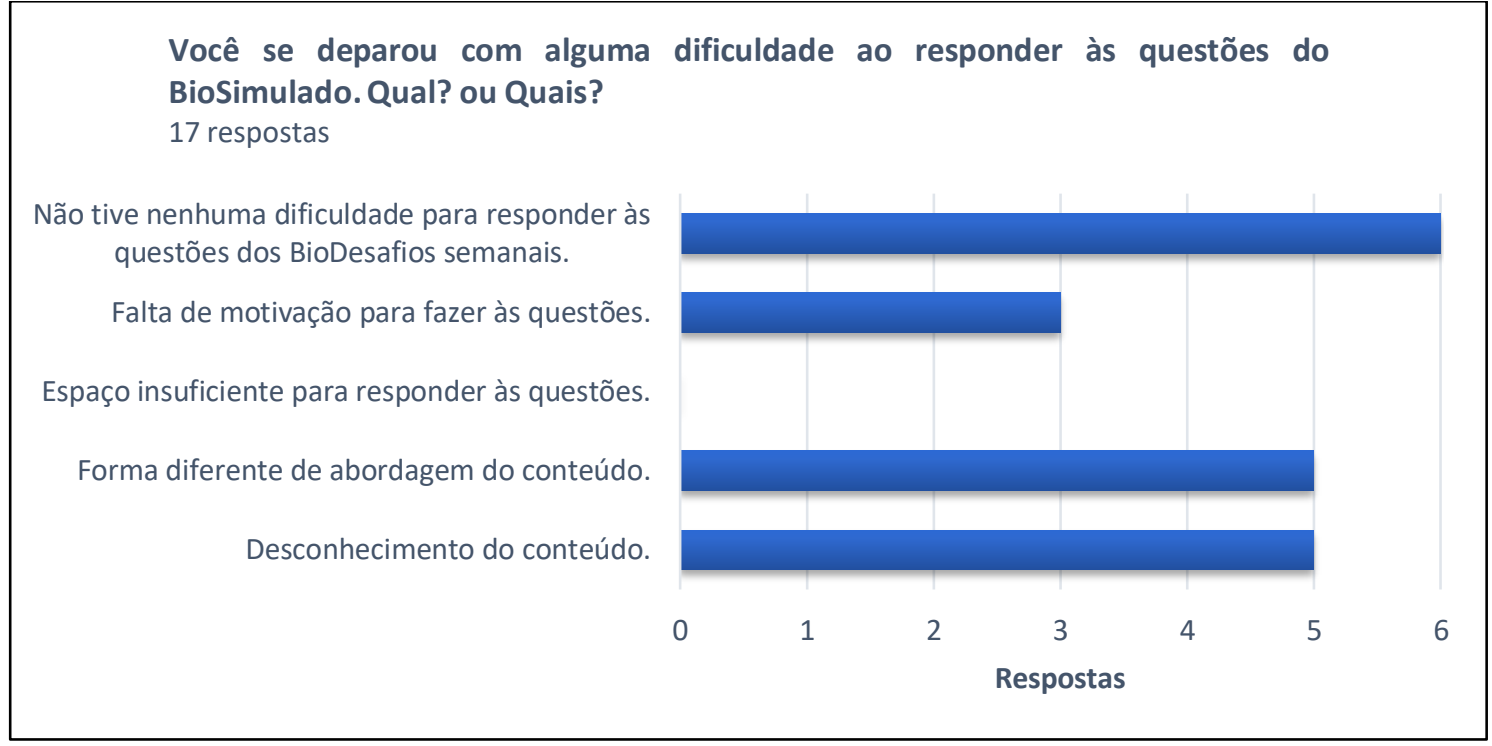

Fonte: Dados da atividade realizada.

Figura 13 - Avaliação dos BioDesafios

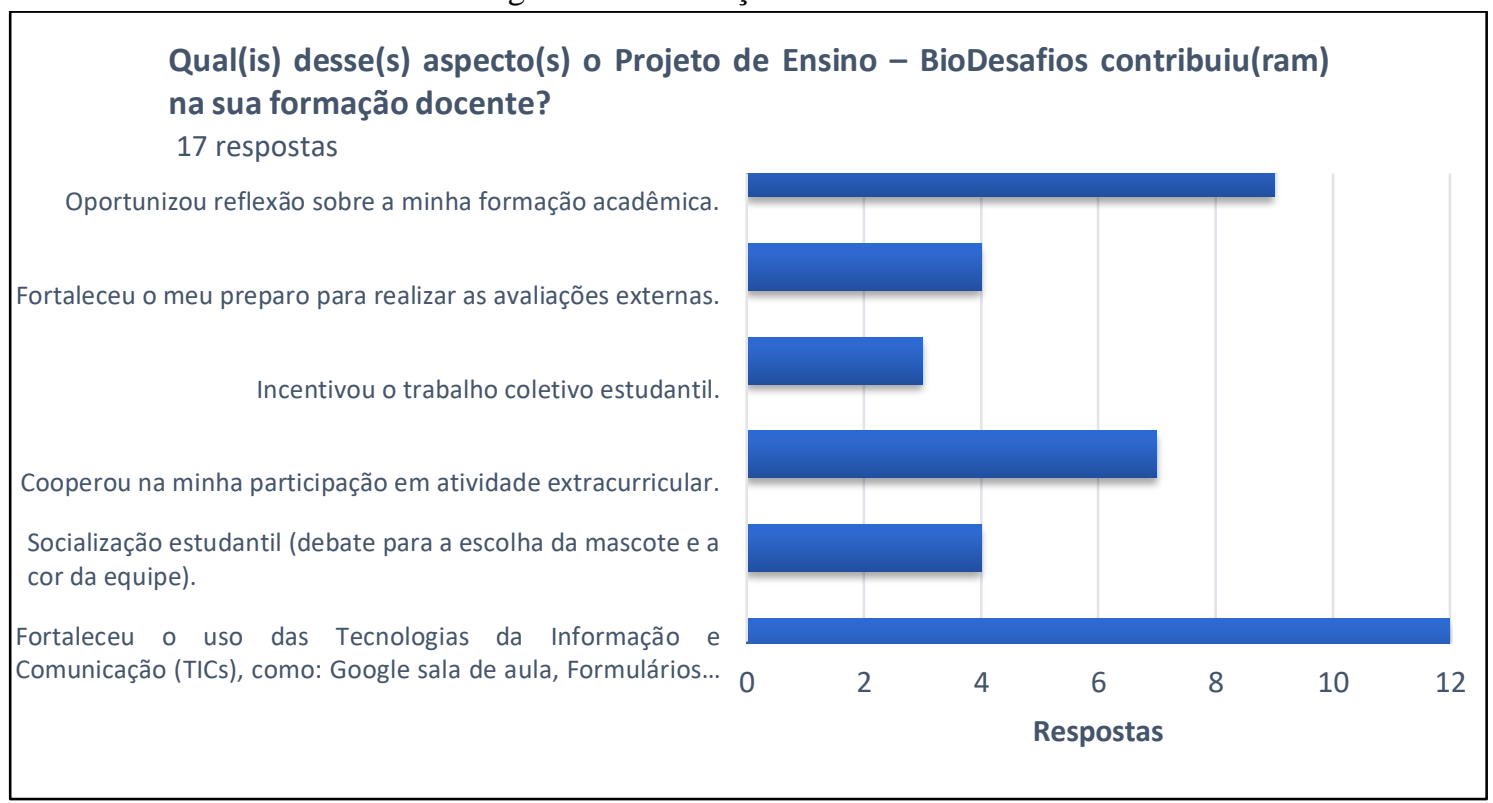

Fonte: Dados da atividade realizada.

Figura 14 - Avaliação do projeto de ensino

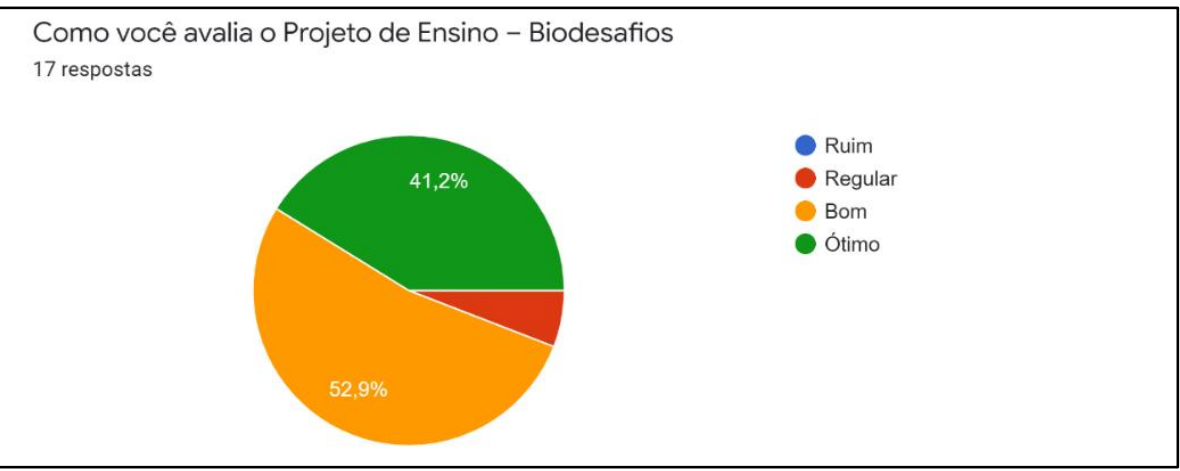

Fonte: Dados da atividade realizada. 
Ainda, durante a execução deste projeto de ensino, pode-se observar o aprendizado significativo dos estudantes, no que lhe concerne, apreciaram a maneira diferenciada de ensinar e aprender (Figuras 11, 12, 13, 14 e Quadro 4). Ademais, nesta seção, as informações apresentadas pelos estudantes encontram-se prenunciadas pela conjuntura do projeto (Figuras 15 e 16). Por conseguinte, os relatos apresentados, especialmente, no Quadro 4, referente aos pontos fortes do Projeto de Ensino - BioDesafios, ressaltam a importância de incentivar o uso de metodologias alternativas aliadas as TICs na formação inicial de professores, como neste projeto, na aplicação da metodologia de ensino participativa, empregada no projeto, e da utilidade desta metodologia se tornar praxe na formação docente.

Entretanto, alguns estudantes relatam no Quadro 5, relativo aos pontos fracos ou a ser fortalecidos no Projeto de Ensino - BioDesafios, as dificuldades: no uso das TICs, na comunicação entre professor-estudante e estudante-estudante, na contribuição dos estudantes em atividades de grupo e na relação com o líder do grupo. Estas refletem as dificuldades constatadas também em alguns estudantes no ensino presencial. Porém, a avaliação do projeto realizada pelos estudantes indica a sua aprovação, com 41,2\% ótimo; 52,9\% bom e 5,9\% regular - 1 estudante - (Figura 14). Diante disso, torna-se emimente a oferta do Projeto de Ensino BioDesafios para as demais turmas do curso de licenciatura em Ciências da Natureza com Habilitação em Biologia do Campus Avançado, com destaque, no período de ensino "híbrido" e a possibilidade de compor parte da carga horária do curso pela modalidade da Educação a Distância (EaD). Além da adequação do Projeto de Ensino - BioDesafios aos anseios educacionais.

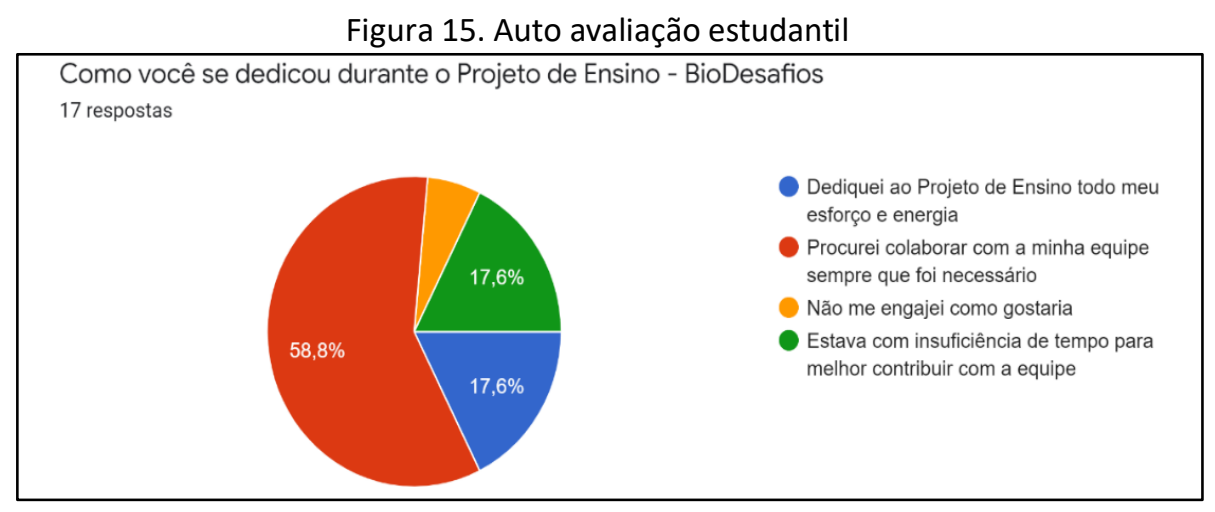

Fonte: Dados da atividade realizada. 
Figura 15 - Auto avaliação estudantil

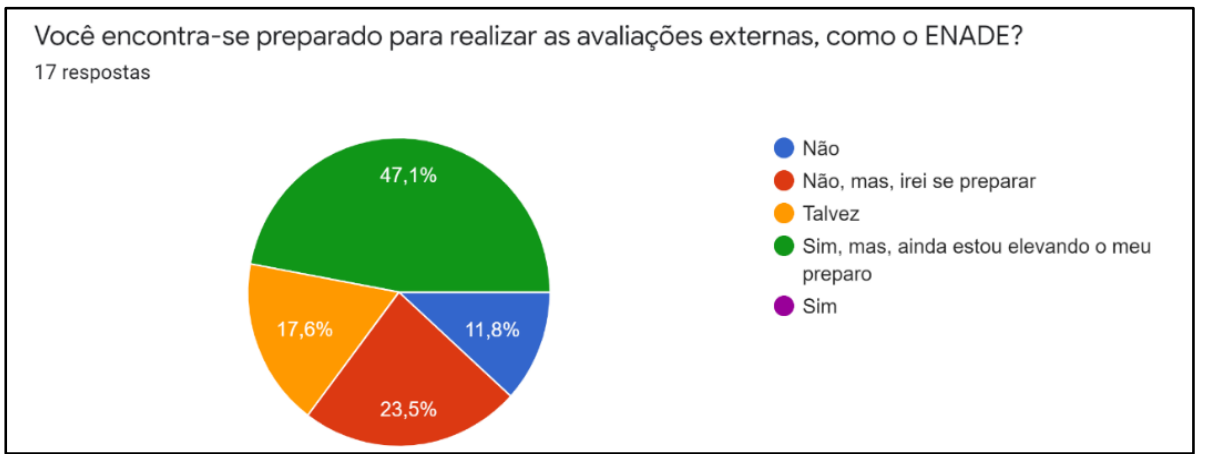

Fonte: Dados da atividade realizada.

Quadro 4 - Projeto de Ensino - BioDesafios: pontos fortes

Pontos fortes do Projeto de Ensino - BioDesafios:

17 respostas

1. Colaboração na formação acadêmica.

2. Trabalho em equipe.

3. Preparação para o Enade.

4. Busca pelo conhecimento, além de fortalecer o uso das tecnologias.

5. O trabalho em equipe criando novas formas de trabalhar em grupo onde todos podem fazer suas contribuições.

6. Fortaleceu o conhecimento conforme as pesquisas e atividades propostas facilitando o aprendizado junto a teoria e a prática adquirida.

7. Promoveu conhecimento, a partir de orientações relacionada ao uso da tecnologia de informação atual.

8. O projeto dá tempo suficiente para estudar, pesquisar e ter mais confiança em elaborar as questões.

9. Abordar os conteúdos para preparação do ENADE, mesmo nos tempos de pandemia.

10. Uso das mídias ou tecnologias de informação e comunicação para disseminar o conteúdo e nos preparar para avaliações como o ENADE.

11. As atividades são adequadas e os conteúdos são interessantes.

12. Trabalho em equipe, experiência em responder questões de nível ENADE.

13. Ajuda relembrar conteúdo.

14. Serviu como um preparatório para o ENADE.

15. Colaborou com o fortalecimento do conhecimento sobre os temas abordados.

16. Trabalho em grupo e uso das TIC's.

17. Contribuiu para minha formação.

Fonte: Dados da atividade realizada.

Quadro 5 - Projeto de Ensino - BioDesafios: pontos fracos ou a ser fortalecidos

Pontos fracos ou a ser fortalecidos no Projeto de Ensino - BioDesafios:

17 respostas

1. Instrução aos alunos envolvidos.

2. Falta de compromisso.

3. O modelo EaD, pois, dificultou a comunicação.

4. Achei o projeto muito satisfatório.

5. O estímulo para que todos possam ter tempo para trabalhar em grupo.

6. Falta de colaboração do grupo, alguns não demonstrou interesse em colaborar com as atividades propostas.

7. Interação mais ativa de todo grupo.

8. Cobrar a participação de todos da equipe, à elaboração das atividades.

9. Para fortalecer ainda mais, é necessário o contato direto com os integrantes das equipes e com o professor para um aprofundamento dos conteúdos.

10. Apenas indico que as questões deveriam ter respostas editáveis para todos os integrantes da equipe.

11. Falta de comunicação entre líder e equipe.

12. Nada a relatar. 
13. Apenas o líder por mandar respostas

14. Por ser a distância existe uma dificuldade na comunicação, de forma a tornar a mesma mais clara e objetiva.

15. A colaboração ou incentivo dos próprios grupos.

16. O fato de apenas uma pessoa ser a encarregada de enviar as respostas.

17. Falta de mais encontros e reuniões via Meet.

Fonte: Dados da atividade realizada.

Assim, a finalidade da prática dos BioDesafios incorporada a metodologia participativa consiste nas imposições de uso das TICs, interação estudantil dialogada, hábito da aprendizagem colaborativa, fortalecimento da empatia, valia do protagonismo estudantil, senso de responsabilidade e liderança, afeição a hierarquia, convivência com as opiniões contraditórias e inevitabilidade das práxis de convencimento didático-científico.

\section{Conclusão e Perspectivas futuras}

Aplicabilidade das questões interdisciplinares e integradoras no formato digital como os BioDesafios e BioSimulado contribuíram para o fortalecimento do processo de ensino e aprendizagem dos futuros professores - estudantes do curso de licenciatura em Ciências da Natureza com Habilitação em Biologia do Campus Avançado -. Em adição, constata-se a eminência das ferramentas tecnológicas educacionais empregadas durante a execução do projeto de ensino, além da possibilidade de detectar a partir dos BioDesafios e BioSimulado às possíveis lacunas e fragilidades no conhecimento estudantil. Portanto, espera-se também, a obtenção de rendimento estudantil adequado diante das avaliações externas. Além disso, o projeto de ensino possibilitou a geração exitosa de estratégias de ensino. À vista disso, os resultados didático-pedagógica-andragógicas adquiridos no decorrer da execução desse projeto, em especial, a partir das aplicações de BioDesafios, baseados em QSCs aliados as TICs, são balizadoras para concepção de uma metodologia de ensino.

\section{REFERÊNCIAS}

ALVES, Raissa Mirella Meneses; GEGLIO, Paulo César; MOITA, Filomena Maria Gonçalves da Silva Cordeiro; SOUSA, Cláudia Niedes da Silva; ARAÚJO, Maria Simone Medeiros de. O quiz como recurso pedagógico no processo educacional: apresentação de um objeto de aprendizagem. In: CONGRESSO INTERNACIONAL DE TECNOLOGIA NA EDUCAÇÃ̃O, 13, 2015, Recife. Anais... Recife: Fecomércio-PE, 2015. Disponível em: http://www.pe.senac.br/congresso/anais/2015/arquivos/pdf/comunicacaooral/O\%20QUIZ\%20COMO\%20RECURSO\%20PEDAG\%C3\%93GICO\%20NO\%20PROC ESSO \%20EDUCACIONAL\%20apresenta\%C3\% A7\%C3\%A3o\%20de\%20um\%20objeto\%20 de\%20aprendizagem.pdf Acesso em: 03 dez. 2020.

ANVISA. Agência Nacional de Vigilância Sanitária. Protocolo de Manejo Clínico para o Novo Coronavírus (2019-nCoV). Portal Brasil, 2020. Disponível em: 
https://portalarquivos2.saude.gov.br/images/pdf/2020/fevereiro/11/protocolo-manejocoronavirus.pdf. Acesso em: 20 nov. 2020.

ARAÚJO, Cristina Maria de Souza. O uso das TICs no processo educativo: exigência do desenvolvimento profissional docente. 2016. 204p. Lisboa: Dissertação (Mestrado em Ciências da Educação) - Escola Superior de Educação Almeida Garrett, Lisboa, 2016.

Disponível em:

https://recil.grupolusofona.pt/bitstream/10437/8250/1/CRISTINA\%20ARA\%C3\%9AJO.pdf . Acesso em: 27 jun. 2021.

ARAÚJO, Gabriel Henrique Messias; SILVA, Amanda Souza Calixto da; CARVALHO, Ludmylla Augusta Souza de; SILVA, Janaína Cristina da; RODRIGUES, Cynthia Waleria de Melo Silva; OLIVEIRA, Gilvaneide Ferreira de. O quiz como recurso didático no processo ensino-aprendizagem em genética. In: REUNIÃO ANUAL DA SBPC, 63, 2011, Goiânia. Anais... Goiânia: SBPC, 2011. Disponível em: http://www.sbpcnet.org.br/livro/63ra/resumos/resumos/5166.htm. Acesso em: 20 nov. 2020.

BARBOSA, Maria Rita Leal da Silveira; MARTINS, Angélica Pinho Rocha. Avaliação: Uma prática constante no processo de ensino e aprendizagem. Revista católica, Uberlândia, v. 2. p. 1-9, 2000. Disponível em:

http://catolicaonline.com.br/revistadacatolica2/artigosv3n5/artigo27.pdf. Acesso em: 10 novembro 2020.

BAZHUNI, Rosayna Frota; DA SILVA, Luciana Ribeiro. Ações de Docência na Pandemia: Desafios e Oportunidades com as Novas Tecnologias Digitais. Revista Carioca de Ciência, Tecnologia e Educação, Rio de Janeiro, v. 5, n. especial, p. 101-103, 2020. Disponível em: https://recite.unicarioca.edu.br/rccte/index.php/rccte/article/view/141/163. Acesso em: 03 dez. 2020.

BRASIL. LEI No 12.056, DE 13 DE OUTUBRO DE 2009. Acrescenta parágrafos ao art. 62 da Lei n ${ }^{\circ}$ 9.394, de 20 de dezembro de 1996, que estabelece as diretrizes e bases da educação nacional. Disponível em: http://www.planalto.gov.br/ccivil_03/_Ato2007-

2010/2009/Lei/L12056.htm\#art1. Acesso em: 01 nov. 2020.

BRASIL. LEI No 13.415, DE 16 DE FEVEREIRO DE 2017. Altera as Leis n ${ }^{\circ}$ 9.394, de 20 de dezembro de 1996, que estabelece as diretrizes e bases da educação nacional, e 11.494, de 20 de junho 2007, que regulamenta o Fundo de Manutenção e Desenvolvimento da Educação Básica e de Valorização dos Profissionais da Educação, a Consolidação das Leis do Trabalho - CLT, aprovada pelo Decreto-Lei $n^{\circ} 5.452$, de $1^{\circ}$ de maio de 1943, e o Decreto-Lei $\mathrm{n}^{\circ} 236$, de 28 de fevereiro de 1967; revoga a Lei $\mathrm{n}^{\circ}$ 11.161, de 5 de agosto de 2005; e institui a Política de Fomento à Implementação de Escolas de Ensino Médio em Tempo Integral. Disponível em http://www.planalto.gov.br/ccivil_03/_Ato2015-

2018/2017/Lei/L13415.htm\#: :text=Nacional\%20Comum\%20Curricular.-

,Art.,Ensino\%20M\%C3\%A9dio\%20em\%20Tempo\%20Integral. Acesso em: 01 nov. 2020.

BRASIL. LEI No 9.394, DE 20 DE DEZEMBRO DE 1996. Estabelece as diretrizes e bases da educação nacional. Disponível em: http://www.planalto.gov.br/ccivil_03/leis/19394.htm. Acesso em: 20 out. 2020.

BRASIL. Ministério da Educação. Portaria n⿳0 14, de 3 de janeiro de 2020. Estabelece o regulamento do Exame Nacional de Desempenho dos Estudantes - Enade, edição 2020. 
Disponível em: http://www.in.gov.br/en/web/dou/-/portaria-n-14-de-3-de-janeiro-de-2020236561998. Acesso em: 20 out. 2020.

BRASIL. RESOLUÇÃO N 2, DE 20 DE DEZEMBRO DE 2019. Define as Diretrizes Curriculares Nacionais para a Formação Inicial de Professores para a Educação Básica e institui a Base Nacional Comum para a Formação Inicial de Professores da Educação Básica (BNC-Formação). Disponível em: http://portal.mec.gov.br/docman/dezembro-2019pdf/135951-rcp002-19/file. Acesso em: 20 out. 2020.

CAFÉ, Laércio de Jesus; SELUCHINESK, Rosane Duarte Rosa. Motivação dos alunos de $3^{\circ}$ ano do ensino médio para prosseguirem seus estudo frente as dificuldades da pandemia Covid-19. Humanidades \& Inovação, v. 7, n. 16, p. 198-212, 2020. Disponível em: https://revista.unitins.br/index.php/humanidadeseinovacao/article/view/3746. Acesso em: 03 dez. 2020.

CONRADO, Dália Melissa. Questões Sociocientíficas na Educação CTSA: contribuições de um modelo teórico para o letramento científico crítico. 2017. 237p. Feira de Santana: Tese (Doutorado em Ensino, Filosofia e História das Ciências) - Universidade Federal da Bahia/Universidade Federal de Feira de Santana, Feira de Santana, 2017. Disponível em: https://repositorio.ufba.br/ri/bitstream/ri/24732/1/Tese-DaliaMelissaConrado-2017-QSCCTSA-Final.pdf. Acesso em: 05 jul. 2020.

DA SILVA, Celso; FIGUEIRA, Cleusa Regiane Stchuk; DOS SANTOS, Jefferson César. (2019). O Google Classroom como ferramenta nas aulas de matemática e física. R.E.V.I. - Revista de Estudos Vale do Iguaçu. N.33/2019/01, n. 33. Disponível em:

http://book.uniguacu.edu.br/index.php/REVI/article/view/70. Acesso em: 05 jul. 2020.

FREIRE, Paulo. A Educação na cidade. São Paulo: Cortez Editora, 1995.

FULLICK, Patrick; RATCHLIFFE, Mary. Teaching ethical aspects of science.

Southampton: Bassett Press, 1996.

GOOGLE. Sobre o Google sala de aula, 2020. Disponível em:

https://support.google.com/edu/classroom/answer/6020279?hl=pt-BR. Acesso em: 20 nov. 2020.

INEP. Instituto Nacional de Estudos e Pesquisas Educacionais Anísio Teixeira. Exame Nacional de Desempenho dos Estudantes (Enade), 2020. Disponível em:

https://www.gov.br/inep/pt-br/areas-de-atuacao/avaliacao-e-exames-educacionais/enade. Acesso em: 10 nov. 2020.

INEP. Instituto Nacional de Estudos e Pesquisas Educacionais Anísio Teixeira. Exame Nacional de Desempenho dos Estudantes (Enade), 2017. Disponível em: http://inep.gov.br/educacao-superior/enade/provas-e-gabaritos. Acesso em: 28 jun. 2021.

MERCADO. Luis Paulo Leopoldo. Metodologias ativa como estudo do meio online no Ensino Superior. In: $23^{\circ}$ CONGRESSO INTERNACIONAL DE EDUCAÇÃO A DISTÂNCIA, 150, 2017, Foz do Iguaçu. Anais... Foz do Iguaçu: UFAL, 2017. Disponível em: http://www.abed.org.br/congresso2017/trabalhos/pdf/150.pdf. Acesso em: 03 nov. 2020.

OLIVEIRA, Ailton Diniz De; MOITA, Filomena Maria Gonçalves da Silva Cordeiro. Quizz na sala de aula: uma ferramenta de inclusão no processo de ensino e aprendizagem de 
matemática. In: CONGRESSO INTERNACIONAL DE EDUCAÇÃO INCLUSIVA, 2, 2016, Campina Grande. Anais... Campina Grande: CEMEP, 2016. Disponível em: https://periodicos.ufes.br/kirikere/article/view/2159. Acesso em: 03 nov. 2020.

REIS, Pedro. Da discussão à ação sociopolítica sobre controvérsias sócio-científicas: uma questão de cidadania. Ensino de Ciências e Tecnologia em Revista, v. 3, n. 1, p. 1-10, jan./jun. 2013. Disponível em:

https://repositorio.ul.pt/bitstream/10451/9577/3/DA\%20DISCUSS\%C3\%830\%20\%C3\%802 0A\%C3\%87\%C3\%830.pdf. Acesso em: 21 nov. 2020.

RIBEIRO, Katia Dias Ferreira. Formação de professores de ciências naturais em uma perspectiva interdisciplinar e crítica: reflexões sobre a contribuição da vivência com questões sociocientíficas na mobilização e aprendizagem de conhecimentos para a docência. 2016. 357f. Tese (Doutorado em Educação em Ciências e Matemática) - Universidade Federal de Mato Grosso, Cuiabá, 2016. Disponível em: https://docplayer.com.br/62653583Katia-dias-ferreira-ribeiro.html. Acesso em: 19 jul. 2020.

RIBEIRO, Katia Dias Ferreira. Metodologia participativa na abordagem de questões sociocientíficas: considerações acerca do diálogo. REAMEC - Rede Amazônica de Educação em Ciências e Matemática, v. 8, n. 2, p. 719-738, 2020. Disponível em: https://periodicoscientificos.ufmt.br/ojs/index.php/reamec/article/view/10219. Acesso em: 22 nov. 2020.

SADLER, Troy. Moral sensitivity and its contribution to the resolution of socio-scientific issues. Journal of Moral Education, v. 33, n. 3, p. 339-358, 2004. Disponível em: https://pubmed.ncbi.nlm.nih.gov/16317839/. Acesso em: 22 nov. 2020.

SILVA, Edivan Claudino Soares da. O Google sala de aula como interface de aprendizagem no ensino superior. In: $9^{\circ}$ SIMPÓSIO INTERNACIONAL DE EDUCAÇÃO E COMUNICAÇÃO (9 SIMEDUC), 2018. Anais... Aracaju: SIMEDUC, 2018. Disponível em: https://eventos.set.edu.br/index.php/simeduc/article/viewFile/9572/4164. Acesso em: 22 nov. 2020.

UNESCO. Organização das Nações Unidas para a Educação, a Ciência e a Cultura. Declaração de Incheon. Educação 2030: rumo a uma educação de qualidade inclusiva e equitativa e à educação ao longo da vida para todos. Brasília: UNESCO, 2016.

VENTURINI, Cintia; CARVALHO, Denis; BORGES, Lidiane; DE SOUZA, Maiara; ROSADO, Vagner; TÓLIO, Francisca; FABBRIN, Jamile. A utilização do Google sala de aula em aula: uma ferramenta complementar para o ensino de ciências. Boletim TécnicoCientífico, v. 5, n. 1, p. 79-84, 2019. Disponível em: https://periodicos.iffarroupilha.edu.br/index.php/boletim-tecnico-cientifico/article/view/79-94. Acesso em: 15 set. 2020.

\section{Agradecimento}

Ao Instituto Federal de Educação, Ciência e Tecnologia de Mato Grosso pela concessão de auxílio financeiro (Edital Proen/IFMT n. 03/2020) e aos estudantes do $7^{\circ}$ semestre do curso de licenciatura em Ciências da Natureza com Habilitação em Biologia do Instituto Federal. 